\title{
Canadian Schools, the League of Nations, and the Teaching of History, 1920-1939
}

\author{
Ken Osborne \\ University of Manitoba
}

\begin{abstract}
Between the First and Second World Wars, the League of Nations attempted to reshape history teaching in the schools of its member-states. The League saw a suitably reformed teaching of history as the most effective vehicle for teaching students about the work of the League of Nations and for instilling in them a global consciousness and a rejection of war. As a result, Canada's provincial departments of education faced recurring League requests for information and suggestions as to how their schools might best implement the League's educational goals. This article examines how Canadian policy-makers responded (or failed to respond) to the League's attempts to reform the teaching of history. It shows that, while they ensured that history curricula included some factual information about the League and its work, they failed to respond effectively to the League's more fundamental attempts to implant the seeds of the "international mind" in students.
\end{abstract}

RÉSUMÉ

Dans l'entre-deux-guerres, la Société des Nations a cherché à remodeler l'enseignement de l'histoire dans les écoles de ses États membres. Elle considérait que le renouvellement de l'enseignement de l'histoire était le moyen le plus efficace d'enseigner aux étudiants le rôle de la Société des Nations et de leur inculquer une conscience globale et le rejet de la guerre. Ce faisant, les ministères de l'Éducation provinciaux au Canada ont dû faire face à des demandes récurrentes de la Société souhaitant obtenir de l'information et des suggestions sur la façon dont leurs écoles pourraient mettre en œuvre ses objectifs éducatifs. Cet article examine comment les décideurs canadiens ont répondu (ou n’ont pas répondu) aux efforts de la Société pour réformer l'enseignement de l'histoire. Il démontre que, bien qu'ils aient veillé à ce que les programmes d'histoire contiennent des informations factuelles sur la Société des Nations et son rôle, ils n'ont pas réussi à répondre efficacement aux volontés de la Société d'implanter une «mentalité internationale » chez les étudiants.

\section{The League of Nations and the Reform of History Teaching}

When the League of Nations was created in 1920, its proponents realized very clearly that its success would depend on the creation of a supportive public opinion, and that the seeds of this opinion had to be planted and cultivated in the schools. ${ }^{1}$ 
As prominent Liberal politician Newton Rowell asked a Toronto audience in 1920: "What is the national ideal which is being taught in the schools of this and other lands today; is it the ideal of domination or of service? The answer to this question has a direct and vital bearing on the future peace of the world. The peace and progress of the world during the next generation depends upon the education of the youth of to-day." ${ }^{2}$ In 1932, in an essay specifically aimed at a student readership, Canada's League of Nations Society put it this way: "You who are young, it is you... who must make the dreams of the world come true." 3

Speaking to a national conference on education and citizenship in 1923, the president of the Canadian Trades and Labour Congress, Tom Moore, declared that "the increasing interdependence of the world made it necessary to study history and geography from a new standpoint and with new ideals" so that "mutual knowledge may increase the spirit of co-operation for the welfare of all the world." 4 The secretary of the Manitoba Teachers Federation delivered a similar message to its members in 1925: "Modern conditions dictate that the international mind and the realization of the essential unity of mankind must be developed in a greater measure in our history classes." 5 A year later, in 1926, University of Manitoba historian Chester Martin told teachers that "the story of the League in every nation ought to form a regular part of the curriculum in schools, colleges and universities, for in the last analysis the success of the League of Nations must depend upon what the boys and girls of today are going to think about these things when they grow up." ${ }^{6}$ Fred Clarke, a McGill University professor of education, took this argument a stage further, declaring that "the whole spirit of our History teaching will have to be transformed... if the League is to become that supreme instrument for the common service that it might become." ${ }^{\prime 7}$ Nova Scotia delivered a similar message to its teachers, advising them that history was "one of the great essentials in training citizens to be not only intelligently loyal to their own land but possessed of a broad tolerance and good will for other lands as well." In the same spirit, a Manitoba curriculum committee in 1927 recommended paying more attention to world history as a way of creating in students "respect for other nations" and "the belief that the continued existence and development of all nations are essential to the development of civilization."

As these examples show, a revised teaching of history was seen as providing the best vehicle for developing an internationalist spirit in the young. Pondering what had caused the Great War and what had turned it into the fight-to-the-death bloodbath it quickly became, many post-war commentators found part of the answer in the kind of history taught in schools. As an American observer put it in 1927: "All texts and instruction exalted the nation to show its superiority to others.... Patriotism became national hatred" and the teaching of history was reduced to "national propaganda, by interpreting all the wars of a nation as defensive with the opponent always being the offensive nation." ${ }^{10}$ A post-war study of history textbooks, organized by the Paris arm of the Carnegie Endowment for International Peace, came to much the same conclusion, concluding that all too often the history taught in Europe's schools was reduced to "le souvenir malsain des erreurs et des querelles du passé." ${ }^{11}$ In short, there was considerable agreement with H. G. Wells's post-First World War claim that 
the war was the result of the nationalist "poison called history" taught in schools, though most observers rejected his call for a single, supranational history to be taught in all the world's schools alike. ${ }^{12}$

Despite the high hopes of some League supporters, the Covenant that defined the powers of the League of Nations made no mention whatsoever of education, largely because the national governments that created the League in 1919-20 were unwilling to relinquish control of schooling, which they saw as essential for implanting a sense of national, not international, identity and citizenship in the young. In 1922, the League circumvented this problem by adopting a French proposal to create the International Committee on Intellectual Cooperation (ICIC), using the term "intellectual cooperation" to include discussion of education, though always insisting that nothing the League of Nations did would ever infringe upon the sovereign rights of its member-states in matters of educational policy. Even so, the ICIC quickly became involved in educational questions, and in 1926 created a "subcommittee of experts for the instruction of youth in the existence and aims of the League" (re-named in 1933 as the Advisory Committee on League of Nations Teaching). ${ }^{13}$

The League's first overtly educational intervention came in 1923 with a request that member-states ensure that their students were taught about the League and the importance of settling international disputes peacefully. This was followed in 1924 by a further request that member-states submit reports on how their schools taught students about the League and the concept of world solidarity. In addition, the ICIC initiated discussion of a process outlining a voluntary (and in the event largely ignored) procedure for the removal of nationalistic and militaristic bias from history textbooks.

In 1931, New Zealand historian Willis Airey outlined the League's approach to teaching history in an essay in the League's journal, Educational Survey. ${ }^{14}$ Describing the increasing interdependence of the world's nations, Airey argued that purely national education was no longer sufficient: "If we believe that international cooperation as expressed in the League of Nations is a possible, right and healthy line of development and is a thing of real importance, then it should be embedded in the ordinary teaching of history" (p. 48). In view of the long time spans covered by most history courses, this meant that history teaching should be organized around themes that would link past and present and illuminate commonalties across cultures, as in the case of the history of food, transportation, work, and the family. In a word, history courses had to be "universal," portraying the past as "the story of man, not just Englishmen, or Frenchmen, or Germans, or Japanese” (p. 50). Thus, teachers must "keep the light thrown on the men, women and children who are the nation and the stuff of history" (pp. 51-52).

This did not mean abandoning national history, Airey argued, but rather treating it as the story of "a section of civilization meeting humanity's problems in a characteristic way" (p. 51). Nor did it mean ignoring local history, whose pedagogical value lay in projects that provided "practical training in the sifting of evidence" and attaining "real understanding that becomes part of the child's mind and influences his outlook" (p. 51). The history curriculum should begin with such prehistoric achievements as 
the control of fire, the development of farming, the use of metals, and the like, and end with "problems of human welfare arising from modern large-scale industry and commerce," all to be taught in ways that required the student to become "an active element in his own teaching" (p. 53). For Airey, as for the League's educationists generally, when history was seen in this way, "one can scarcely conceive of a more fertile field for the use of modern educational methods" (p. 53).

Through the ICIC and its committees, the League of Nations did what it could (though the ICIC was consistently underfunded and lacked political support) to promote the kind of history teaching described by Airey. It sponsored conferences and seminars, encouraged the analysis of textbooks, published a teachers' magazine (the Educational Survey, renamed the Bulletin of League of Nations Teaching in 1934, and discontinued in 1938), and generally urged that history curricula be redesigned to promote the cause of peace and international understanding. More specifically, the ICIC persistently made the case for including in school history curricula specific information about the creation, achievements, and potential of the League of Nations. It was, after all, the League that offered the most practicable means of achieving a world without war and of advancing the cause of international cooperation more generally. The unforeseen result was that national ministries of education, and indeed the League's educational advisors themselves, came to equate what could have been a fundamental rethinking and reform of history education in schools with the much narrower goal of ensuring that history curricula dealt adequately with the creation and work of the League of Nations.

In Canada, for example, all provinces and territories taught some combination of courses in Canadian, British, and European history (with the subject of social studies also beginning to make its appearance in these years), usually beginning in the senior elementary grades and continuing through high school. Canadian educationists agreed that specialized study of the League of Nations was best embedded in courses in Canadian history. This would, or so it was hoped, give the League of Nations a Canadian relevance that would be lacking if it were taught primarily in the context of British or European history. In the elementary grades, this meant creating in students a basic awareness of the League's existence, leaving more detailed study for the high school grades where students would be intellectually capable of more advanced work. No-one seems to have drawn attention to one obvious problem with this scheme: though high school enrolments were steadily increasing in the interwar years, approximately half of the students of high school age did not in fact attend high school. To quote one recent study of school enrolment patterns, "the majority of adolescents... were not touched by the high school experience." 15 Thus, half of Canadian adolescents did not receive the kind of teaching that was designed (however ineffectually) to imbue them with the "League spirit" and the "international mind."

\section{The Canadian Response to the League's Educational Campaign}

Provincial departments of education regularly responded to the League's requests for information about what was being done to teach about the League of Nations in 
their schools. Their reports were not particularly informative, simply describing what was being done to include information about the League in school curricula, though in 1926 Ontario added the cautionary proviso that its officials had "no suggestion to make at present for placing additional emphasis upon the aims of the League of Nations" in its schools. Nova Scotia's 1926 report included the text of a proclamation sent to all Nova Scotia schools, declaring that "Canada and the Empire support the League in the hope of bringing the whole world under the reign of universal law" as enjoyed by the beneficiaries of the "Pax Britannica." Thus, Nova Scotia teachers at all grade levels were directed to teach students about the League so that "every pupil should be able to answer a simple fundamental question on an examination."16

In 1932-33, the provinces replied to a new League request for information about teacher training. They reported that their teacher training programs dealt with the League in their history and civics courses, while the theme of international cooperation pervaded everything they did. Saskatchewan added the comment that, given the multicultural nature of its population, international cooperation was a fact of life in the province. ${ }^{17}$ The Manitoba Normal School voiced a similar sentiment: "Where all nationalities are respected in teacher-training institutions and where each is reckoned a contributor to Canada's wealth, it is certain that there will be one great institution in the country working for peace and international understanding." 18 For some Canadian teachers, the composition of the student body taught its own internationalist lesson. In 1937, for example, a Winnipeg school principal reported that his school did not need to teach international understanding through the formal curriculum: "The English girl who washes the little German girl's face after a nose-bleed does more for international understanding than I could do with many formal talks. The Italian boy who gets hoarse cheering for the Negro member of the school football team does his bit to promote good-will." ${ }^{19}$

It is perhaps worth noting that the League of Nations did not deal with provincial governments directly. As a league of nation-states, it had to address its requests and recommendations to the federal government. However, Canada's federal governments, whether Liberal or Conservative, had no objection to popularizing the cause of the League, always provided that it did not lead to any unwanted international commitments or to any divisive political controversies within Canada. Canadian federal governments were prepared to countenance the League's educational efforts, not least because the League always emphasized that it in no way wished to infringe on the sovereign powers of its member states. Its 1932 message was one of many: "Further, care will have to be taken, particularly in the school, to avoid setting up the international community and the national community in contrast to each other. It is on the national community that we must build. Without the individual mothercountries the world would be a chaos." ${ }^{20}$ In other words, governments had nothing to fear from the League so far as control of education was concerned. As a result, in the field of education, Canada's federal governments simply acted as a courier, relaying the League's requests and suggestions to the provinces and sending their responses back to the League. ${ }^{21}$

By the mid-1920s, all provinces included some treatment of the League of 
Nations in their high school history curricula. Canadian educationists agreed with the League's experts that the mechanics and organization of the League were too complicated for children in the elementary grades and therefore were best taught in the high school. Instead, elementary school curricula sought to teach children to internalize and live by such values as tolerance, cooperation, and, especially, a sense of interdependence. As Ontario's curriculum for the elementary grades noted in 1937, "one of the results of the work in Social Studies should be an understanding of the interdependence of families, of communities, and of nations. This understanding... should help to establish in children's minds an attitude of friendliness and good-will to all." ${ }^{22}$ A Manitoba teacher showed how this might work. Her goal was to "implant the healthy concept of the world's people as a group of friends" and to demonstrate their interdependence. To accomplish this, her students identified imports from other countries, chose a particular country, researched its flag and anthem, explained how to travel there, described how to welcome its people if they came to Canada, and ended with writing letters to children who lived there. ${ }^{23}$ Across Canada, teachers at all grade levels were regularly urged to make at least some mention of the League in their lessons, even with the youngest students. As the principal of the Manitoba Normal School told teachers in 1934, "in every school in Manitoba may their (sic) be a few minutes spent in telling children about the League and its good intentions, and its dependence upon the good-will of Canadians."24

More formal study of the League was reserved for the high school grades. On both pedagogical and practical grounds, the League of Nations' educational experts preferred to integrate teaching about the League into existing history courses rather than pressing for anything more innovative and therefore more difficult to implement. Canada's League of Nations Society argued that teaching about the League entailed "no serious break in courses and curricula — only a little applied thought, a little judicious intention and adaptation by the teacher." 25 The drawback was, as some League supporters pointed out, that this left untouched the more deeply rooted national priorities of the world's school systems, reducing what could have been a radical revision of history curricula to a merely cosmetic addition to curriculum content. Needless to say, the League rejected as unworkable in practice and undesirable in principle the arguments of such internationalists as H. G. Wells that schools throughout the world should teach a uniform world history curriculum based on a common textbook. As an American educationist noted in 1944, "the spirit of education in each nation was not radically affected even when the instruction of youth in the aims of the League of Nations was adopted or textbooks were revised; education for national loyalty and patriotism generally proceeded without any serious change in spirit." ${ }^{26}$

An obvious disadvantage of leaving formal study of the League until the end of a chronologically organized high school history course was that teachers might well run out of time before they got to it. Provincial departments of education came up with two solutions to this problem. One was to urge teachers to incorporate references to the League into their teaching wherever possible. The other was to include compulsory questions on the League in final examinations set and marked by provincially appointed examiners. 
Regarding the first approach, provincial teachers' magazines frequently ran articles examining some contemporary issue in world affairs that made some mention of the League of Nations while also offering suggestions as to how to approach it in the classroom. To take only one example, Ontario's The School published articles on such current international crises as Italy's invasion of Ethiopia, Germany's occupation of the Rhineland, Palestine, the Polish Corridor, the Sino-Japanese War, Manchuria, and others, designed to provide background information for classroom use. In 1927, a Manitoba curriculum review committee recommended, though without success, that 10 per cent of class time in high school history courses and 10 per cent of the questions on final examinations should be devoted to current events. ${ }^{27}$ In 1937 , the Ontario Department of Education made a broadly similar point, encouraging teachers to include current events in their teaching even in the elementary grades and noting that "it is worth while for a child to realize that history is being made every day, and that what he reads about in the daily paper may some day appear in a history book." ${ }^{28}$ It is difficult to imagine that history teachers, especially in the crisis-laden 1930s, would not have made some reference to current events in the course of their regular teaching. As a London, Ontario, teacher wrote in 1935: "No good teacher of history fails to illustrate all his lessons without reference to daily happenings in the world." ${ }^{29}$ At Weyburn Collegiate in Saskatchewan, for example, grade 12 students were required to debate such issues as the Locarno treaty, Germany's reoccupation of the Rhineland, and the issue of oil sanctions against Italy, focussing on such questions as "Ought British, and perhaps Canadian youth, to be called to the colours to defend one of the nations under the Locarno pact?" ${ }^{30}$ In addition, high schools across Canada organized student conferences, essay contests, mock League assemblies, and other such measures in an attempt to stimulate students' interest in current affairs and the League. In Woodstock, New Brunswick, for example, high school students met annually with their American counterparts from Richer Academy in Maine to discuss current affairs and listen to visiting speakers, while in Stanstead, Quebec, Canadian and American students joined in staging an annual mock League of Nations Assembly. ${ }^{31}$

In addition, some high schools created current events clubs and, though much less frequently, League of Nations clubs. ${ }^{32}$ A 1935 Toronto survey of eighteen high schools found three current affairs clubs and one League of Nations club in existence. ${ }^{33}$ In 1936, a Manitoba school inspector listed the school clubs that existed in his rural inspectoral district. They included thirty Junior Red Cross clubs, twentythree sewing clubs, fifteen garden clubs, thirteen athletic clubs, and even five potato clubs and three bacon hog clubs. There were also two debating clubs, but no League of Nations or current affairs club, though it is possible the two debating clubs considered League issues from time to time. ${ }^{34}$ As this example suggests, Junior Red Cross clubs were especially popular with Canadian schools, and provincial departments of education encouraged their creation. Much of their work was tied to domestic concerns, but they also took an interest in international affairs and especially in international letter-writing projects based on the belief that, if children could be brought to sympathize with children in other countries, then the "unspeakable horrors of the 
last few years" would never be repeated and "peace will reign on earth." 35 Indeed, according to one observer, the Junior Red Cross "might be called the junior section of the League of Nations." 36 This kind of activity sometimes took the form of preparing a report ("portfolio" was the word of choice) on students' own school and community and exchanging it with similar reports from students elsewhere in the world. According to a Manitoba observer writing in 1937, there were "hundreds of these now being made in the province every year." 37

In addition to their treatment of current events, Canadian teachers' magazines opened their pages to the League. In 1926, for example, the Winnipeg-based Western School Journal published a "Draft Syllabus for a Lesson on the League of Nations" running from the founding of the League, through its organization, and ending with its activities in health, science, international cooperation, and the mandate system. ${ }^{38}$ In the same year, the $B C$ Teacher published a series of articles by UBC historian F. H. Soward describing "The Past, Present and Future of the League of Nations," while in 1927 the Western School Journal ran a series of articles written by local academics, aimed at teachers and featuring different aspects of the League's work. ${ }^{39}$ From time to time, provincial teachers' magazines also reprinted important League documents, for example, when the Manitoba Teacher in 1927 published the recommendations of the League's subcommittee of experts on League teaching or in 1928 when the $B C$ Teacher reprinted the text of the Kellogg-Briand Pact for the outlawing of war. ${ }^{40}$

This wave of activity reached the point that in 1928 one Manitoba teacher felt constrained to protest, asking "Do you not think the League of Nations has been worn threadbare in our monthly magazine?" and drawing an indignant response from the president of the local League of Nations Society. ${ }^{41}$ This was very much a minority voice, however, and Canadian teachers' organizations overwhelmingly threw their support behind the League. In addition, provincial departments of education did what they could to make up-to-date material describing the League available to teachers and sometimes directly to students, with the League of Nations Society's 1927 booklet, $A$ New World, attracting particular attention. Manitoba required its use in grade 10 and Nova Scotia and British Columbia distributed it free to their schools. The booklet set out the main facts about the aims, organization, and achievements of the League and, judging by internal evidence, was a scaled-down version of a booklet produced in 1924 by University of Alberta historian A. L. Burt for the Extension Department of the University of Alberta and used in Alberta's high schools. ${ }^{42}$

Another way of ensuring that high school history teachers did not ignore the League was to warn them that provincial examinations in history would include a question dealing with the League's activities. In 1926, Ontario included this question in its end-of-year grade 10 history examination: "What is the League of Nations? What are its chief aims?” In 1927, British Columbia's final examination for grade 11 contained this question: "List some of the important accomplishments of the League of Nations. Give three reasons for its failure to accomplish more." In 1928, the question was: "Account for the creation of the League of Nations; do you think it has justified its existence?" Similarly, in Manitoba, the final examination in grade 9 history in 1931 included this compulsory question: "Write about the League of Nations 
under the following heads: (a) need for a League; (b) the Council and the Assembly; (c) the Permanent Court of Justice; (d) any three accomplishments of the League." In 1936, Manitoba's grade 12 history examination included this question: "Describe the organization of the League of Nations." ${ }^{43}$ For a few years after 1927, Manitoba also advised grade 10 students that they would not be allowed to write their final examinations unless their teachers signed a form declaring that they had studied the League of Nations Society's booklet, A New World, in class.

There were obviously history teachers who taught their subject well and the pedagogical literature in the interwar years was full of suggestions about how to teach history more effectively. The work of John Dewey, William Kilpatrick, and Harold Rugg was frequently cited in provincial teachers' journals, and it played an important part in the adoption of the activity-based "enterprise" method in the mid-1930s in Alberta and other provinces. ${ }^{44}$ This said, however, school inspectors across Canada described much history teaching as dull and uninspiring. In 1925, for example, a New Brunswick inspector reported that "too often the lesson is merely a matter of words learned by heart without an understanding of their meaning, the lesson being directed by the teacher with text book in hand." ${ }^{5}$ Toronto's school inspectors said much the same thing in 1932, faulting teachers for relying too heavily on "the memorization method" with its attendant apparatus of repetition, drill, cramming, and recitation. ${ }^{46}$ A Manitoba curriculum committee had reached much the same conclusion in 1927, noting that all too often history at all grade levels was reduced to "notes which are memorized for the examination and quickly forgotten," with the result that students did not see the value of the subject and left school "with no desire to continue it longer than necessary." ${ }^{47}$ Alberta reported in 1935 that "history is generally limited to the textbook, without the vital relation of its development to present day problems." 48

Similar assessments can be found in all provinces, and many university historians seem to have agreed. According to University of Toronto historian George Wrong, writing in 1921, "The very name of History repels students coming to the University and this is due to bad work in the schools." ${ }^{49}$ In 1925, the president of the Canadian Historical Association declared history to be "one of the weakest subjects in the school curriculum." ${ }^{0}$ In Nova Scotia, the province's chief inspector concluded that it might be best not to teach history at all, leaving it to the "post school period, especially as its philosophical aspects make weak appeal to minds of high school age." ${ }^{1}$ If such observers were correct, then teaching about the League of Nations, which was generally integrated into history classes, presumably suffered accordingly. Some observers wondered whether simply including League material in an existing history or civics course was likely to achieve anything worthwhile. According to the principal of Queen's University, speaking in 1934, “a formal course of instruction in League business, embodied in a textbook and prescribed for examination [,] might inspire a permanent distaste for the collective system, comparable to the distaste for English literature induced by rigid methods and prescription and examination." 52

Nonetheless, whatever its actual impact in the classroom, the emphasis on global citizenship and its embodiment in the League of Nations (though always as an 
extension of, never as a substitute for, national citizenship) seems to have resonated with many Canadian educationists in the interwar years, even if only on a rhetorical level. Alberta's Department of Education spoke for most provinces when it declared in 1927 that the study of history must "play its part in raising young Canadian citizens from the idea of narrow nationalism, or even imperialism, to a higher plane of internationalism, where they will be swayed by no prejudice of race, creed or tongue." ${ }^{33}$ In the same year, the superintendent of Winnipeg schools made a broadly similar point, calling for a "radical revision of courses in history, both as to material and method of study" so as to incorporate "such material from world history as will make clear the causes, the nature and the effect of war on the well-being of civilized nations." ${ }^{54}$ A few years later, in 1935, Nova Scotia took up the call, insisting that "history must not be taught so as to engender a narrow patriotism" (italics in original) but rather to instil in students an appreciation of the "effort and sacrifice" that had gone into the building of society, comprising both "community or nation, in the narrow sense[,] and humanity itself in the wider sense." 55

Nova Scotia's 1935 grade 9 civics program showed how this might be done. Though largely focussed on character training and moral education, the program contained two units of study entitled "Nature of World Government" and "Study of War," though their emphasis was on the cultivation of international understanding generally rather than on the League of Nations specifically. Thus, for example, five "duties of the citizen in the world community" were defined: (1) appreciation of other peoples; (2) courteous treatment of foreign visitors; (3) determination not to judge without facts; (4) commitment to all agencies working for world fellowship; and (5) welcoming immigrants. More provocatively, the unit of study entitled "Study of War" ended with two suggested debate topics, designed to show that history could be more than the memorization of facts. The first was: "Resolved that war must be abolished if civilization is to survive." The second was more pointed and, one would have thought, more controversial: "Resolved that explorers, doctors and writers have contributed more to the world than soldiers. ${ }^{56}$ However, since civics was scheduled for only two class periods a week, and these two units formed part of a longer course, they would presumably have been dealt with fairly lightly.

The emphasis on a new kind of global citizenship led some League activists to look for ways to break out of the confines of orthodox pedagogy. Mary McGeachy, for example, a former Hamilton high school teacher who worked in the League secretariat, told an audience of teachers in 1930, in a speech that she repeated across Canada, that schools would not address "the root of the problems of international peace if we think of it in political terms only." Rather than dwelling on the organization of the League, she argued, teachers should draw on what the League actually did in the world: "How much better than describing the actions of the Secretariat to tell the story of the time when the health organization was called upon to deal with an epidemic of sleeping sickness in Central Africa" with the attendant drama of medical mobilization, creating emergency treatment centres, finding trained personnel, establishing quarantine procedures, procuring adequate transportation, and all the rest. ${ }^{57}$ Outside the history classroom, schools took advantage of commemorative 
ceremonies that could be used to promote international understanding and peace. Across Canada, though most especially in British Columbia, Goodwill Day was celebrated every May 18 to mark the 1899 international peace congress at The Hague and provided an opportunity for addressing League themes. ${ }^{58}$ In addition, Remembrance Day was often given an explicit anti-war message with at least a reference to the League of Nations. In this spirit, in 1925 the Western School Journal addressed a special Remembrance Day column to elementary school students, telling them they should remember that war meant "cold and suffering and wounds and dirt and noise and horrors" and "terrible things that we do not want to think of, including lonely homes, men walking lame and blind, and crippled for the rest of their lives." Thus, when children thought of war on Remembrance Day, "we must remember this and make up our minds that when we are grown men and women... never, never, if we can help it, shall there be war again." And to ensure that there would not be, in a "little town in Switzerland," people were working to find ways to keep the peace. ${ }^{59}$

Even Empire Day could be enlisted in the cause of peace, and many Canadian imperialists were inclined to see the British Empire as a shining example of international cooperation in action. In this spirit, in 1921 Manitoba's Department of Education suggested that the province's schools organize Empire Day celebrations around the achievements of four Empire-builders - La Vérendrye, Wolfe, Selkirk, and Dufferin - while also emphasizing that the Empire was above all a force for world peace, and that in any future war, there would be no victors. To quote the official booklet: "It needs but a moment's reflection to realize that with the inevitable advance in the efficiency of death-dealing appliances a war in fifty or even twenty years' time must assuredly thrust civilization back into the chaos from which it has so slowly and painfully emerged." 60

Where circumstances permitted, local branches of the League of Nations Society in Canada and such anti-war groups as the Women's International League for Peace and Freedom lobbied provincial departments of education and school boards, made speakers available to schools, provided teaching materials, sponsored essay contests, organized League of Nations days and peace conferences, and generally did whatever they could to advance the League's educational agenda. In addition, the Ottawa-based League of Nations Society in Canada used its monthly (quarterly after 1931) journal, Interdependence, to publish material that it hoped teachers and students might find useful. Its 1927 booklet about the League, A New World (replaced in 1935 by a new version entitled Highway to Peace) was made available to schools, as were other proLeague publications, as and when the Society's resources permitted. ${ }^{61}$ In addition, where local interest existed, the Society sponsored the creation of junior branches, not only in such urban centres as Toronto, Halifax, and Vancouver, but also in such smaller communities as Salmon Arm, BC, and Brandon, Manitoba.

No doubt inspired by the League's campaign, Canadian educationists paid some attention to a favourite League cause - the revision of history textbooks. In 1925, for example, a group of teachers in southeastern Manitoba independently set out to investigate their textbooks for signs of nationalist bias, concluding that "material glorifying war is not excessive." ${ }^{2}$ The most elaborate Canadian investigation of history 
textbooks was organized by the Toronto Branch of the Women's International League for Peace and Freedom, which in 1933 published a detailed survey of the history texts used in all provinces except Quebec. Of the books that were considered relevant for the survey, five were found to say nothing about the League, five made only the briefest comment, twelve were judged to be more or less satisfactory, and five were judged to view the League very favourably, though all were faulted for providing too little information about the League and its work. The most striking weakness of the textbooks, however, was found to be not bias or belligerence but the fact that they were "dull and uninteresting, and history should and could be made the most fascinating of the humane studies embodied in the curriculum" (emphasis in original). ${ }^{63}$

The survey organizers offered history teachers six "ideals for textbooks." One, they must be designed to "cultivate attitudes" and be chosen carefully for their "historic worth and accuracy." Two, when learning about conflicts between nations, students should be presented with the relevant facts, so that they could form their own conclusions with no attempt by teachers or textbooks to define the justice or injustice of the issues at stake. Three, teachers and textbooks must do everything possible "to relieve national jealousies and racial hatreds." Four, historical subject-matter should be selected and taught "with unfailing regard for those characteristics and events which have resulted in the advancement of the race toward freedom, better modes of living, culture, and the realization of ideals." Five, students must be taught that "civilization and its advance is marked by the turning away from the military and accepting the civil rule." Six, great events and characters should be presented to students in such a way that they understand "the relationship of events to individuals." 64

Canadian history textbooks published in the 1920s and 1930s in fact avoided the bellicose nationalism that McKay and Swift have recently described as "Vimyism."65 They described the German government as being primarily responsible for the outbreak of war in 1914, but they also explained that Germany's actions had to be seen in the context of European politics more generally; they then went on to describe Canada's involvement in the war without any attempt to minimize the reality of the fighting. Thus, for example, Winnipeg teacher and war veteran, George Reeve, in his 1926 textbook, began his description of the war by pointing to what he described as Germany's exaggerated sense of nationalism, but went on to say that "Germany's example in the matter of imperialism was widely followed by other nations," while the "most powerful single factor in bringing about the Great War was the mighty armaments that the leading European powers had built up." "In his 1927 textbook, Queen's University historian Duncan McArthur told students that Europe's policymakers "had not realized the extent to which the world had become interdependent" so that "selfish ambitions thus remained uncurbed and were allowed to work havoc and destruction." ${ }^{67}$ For his part, University of Toronto historian William Wallace told students in his 1928 textbook that opinions as to who or what was responsible for the war were "still divided" but the "real cause of the War" was to be found in the division of the European powers into two rival alliance systems, "each fearful of the other." 68

All Canadian textbook authors described the military prowess of Canada's soldiers, but, at the same time, spared no efforts in describing the horrors of the trenches. For 
the University of Toronto's George Wrong, Canada's soldiers were “ranked among the best troops in the fighting line," but he also told his student readers that "Canadian troops... stood in mud and slime behind earth embankments... To show a head above the embankment was to attract instant deadly rifle-fire... Hovering above the hostile lines, aeroplanes dropped deadly bombs... No means to destroy life," Wrong concluded, "was spared in the awful struggle." ${ }^{69}$ Reeve wrote in a similar vein: "Men came back telling of the miseries, filth and horrors of trench life; of the death that came to their comrades in a thousand ghastly shapes; of men screaming with the agony of their wounds. The shell-shocked, the blinded and the maimed came back, and Canada began to realize the full meaning of modern warfare."70

At the same time, however, textbook authors found ways to place the war in the wider context of the nation-building narrative that was the organizing theme of textbook history. For McArthur, the war marked Canada's "coming of age" as a nation. ${ }^{71}$ For Wallace, "it is to be hoped that never again will the Canadian people be called upon to endure the ordeal through which they passed in the tragic years of 191418 , but it is a satisfaction to every Canadian to know that he can look back on his country's record during these years without shame or regret." 72 For Reeve, "the most important achievement of the Great War was to turn the attention of all nations to the vital necessity of providing means for the prevention of future wars." 73 And, of course, the hope was that the League of Nations offered such a means: "With the other peoples of the world, Canadians had come to realize the futility of settling disputes by resort to arms. Canada had lived at peace with her nearest neighbour for more than a hundred years and had learned of a better way of preserving accord among the nations." ${ }^{4}$ Moreover, Canada's war record gave her "the right to be heard in the councils of the world, where her voice will be raised on behalf of peace and international goodwill."75

Even so, history textbooks did not avoid controversy completely. In British Columbia, W. L. Grant's History of Canada came under attack in 1920 when ultrapatriotic Canadians criticized it for being pro-German (in addition to being too sympathetic to Louis Riel and to francophone Canada more generally) and insufficiently pro-British. Even the name of the British publisher of the 1916 edition of Grant's textbook - Heinemann — was condemned for its German-ness. Although Grant's text was defended by UBC historians and others, and despite his distinguished war record and impeccable personal credentials, the provincial Department of Education withdrew it from the province's schools. ${ }^{76}$

In New Brunswick in the same year, a different controversy arose. Ever since 1910, the province had been using a world history textbook written by an American historian-P. V. N. Myers' A General History for Colleges and High Schools-but in 1920 , when a new edition was authorized for provincial use, patriotic critics quickly pointed out that it made no mention of Canadians' involvement in the Great War. As was the case in British Columbia, the New Brunswick Department of Education withdrew the textbook only to find that the search for an alternative text raised other complications rooted in the province's religious and political rivalries. Unable to find a suitable replacement, the department temporarily solved its problem by limiting its 
European history course to the history of Greece and Rome, thereby hoping to avoid inflaming sectarian antagonisms. ${ }^{77}$ In both provinces, the quarrels were short-lived but, if nothing else, they served to remind Canadian policy-makers that history could always raise political hackles and thus had to be treated carefully as a school subject.

Overall, Canadian history textbooks in the interwar years were reasonably dispassionate in their treatment of issues of war and peace and, to that extent at least, were consistent with the guidelines suggested by the League's educational experts. Missing, however, was any trace of the "international mind" that the League saw as so central to the kind of history teaching it favoured. Rather, Canadian history textbooks incorporated their discussion of war into the wider nation-building theme that inspired and shaped their description of the past. In his 1926 text, Reeve reflected the goal of all interwar Canadian history texts when he wrote that his book was designed "to instil into those who read it a thorough-going spirit of patriotism which[,] while not wholly ignorant of the mistakes of the past, may yet express itself in a proper and predominant love of country, based on a healthy pride in its past record and a firm belief in its future greatness." ${ }^{\prime 8}$ As this quotation reveals, Canadian history texts met what might be called the negative criterion defined by the League of Nations as the refusal to glorify war but not the League's more positive criterion of using history to imbue students with a sense of global solidarity.

The standard textbook pattern was to devote three or four pages to the League while also explaining why Canada preferred to see it as a forum for conciliation and negotiation and not as an instrument of collective security prepared to take coercive measures against an aggressor. In the words of McArthur's high school history textbook, authorized for use in Manitoba, Nova Scotia, Ontario, British Columbia, and Saskatchewan, Canada's foreign policy rested on two principles: one, Canada would do nothing that would create "serious dissension" among Canadians and, two, collective action did not necessarily involve the use of force, which could be authorized only by the Canadian parliament. This said, the textbook, like most of its kind, ended with an upbeat message: "It was the belief of Sir Robert Borden, expressed at Geneva in 1930, that the highest service of the League to humanity lies in the constant association and co-operation, in the resultant education and training of the nations."79

The Ontario texts of 1928 and 1930 written by the University of Toronto historian William Wallace delivered a similar message, noting that the League had "wrought wonders" so that "it is not too much to say that, in various ways, it has helped to make the world a better place in which to live." ${ }^{\prime \prime}$ In both texts, Wallace refrained from saying anything about Canada's active role in making sure the League never possessed any real executive power, concluding instead that "Canadians have a right to be proud of the part Canada has played in the formation and working of the League" and that Canada has "exerted on the work of the League an exceptional influence." 81 The most pan-Canadian French-language history text used in Quebec high schools, published in 1935, devoted only two brief and baldly factual paragraphs to the League, describing the organization of the League, the election of Senator Dandurand to the presidency of the League of Nations Assembly, Canada's three-year term on the League Council, and, as with all textbooks in both English 
and French, emphasizing the symbolic importance of Canada's League membership: "C'était là encore une avance vers l'égalité de statut avec la Grande-Bretagne ellemême." ${ }^{2}$ Nothing was said about the work, achievements, or for that matter, the failures, of the League.

One finds echoes in Canadian history curricula in the interwar years of two favourite themes of League efforts to reform the teaching of history: (1) the emergence and progress of "civilization"; and (2) an emphasis on social history. Totally apart from the League's work, the absence of social history from Canadian history curricula and textbooks attracted its share of critics in these years. In 1924, for example, Queen's University historian Duncan McArthur (subsequently deputy minister and minister of education in Ontario) decried what he saw as the over-emphasis on political history in curricula and argued that the core of school history should be "the actual life of the Canadian people - our own ancestors, flesh and blood such as we are - in their efforts to secure a livelihood and then to provide for the higher demand of mind and spirit." ${ }^{33}$ For the McGill educationist, Fred Clarke, the remedy for what he called the "futilities of current History teaching" was to "take family relationships and houses and food-getting, and clothing, and money and shops, and postage-stamps, and communications and policemen, and dust-carts, and all the rest of it" and trace their evolution across time and cultures. ${ }^{84}$ A 1927 Manitoba curriculum committee made a similar point, noting that history teaching had been too concerned with politics and war, and that time had now to be found for the study of how "men have gained their living and increased their comfort, the story of industry and prosperity, the way in which the world's work has been done...." ${ }^{85}$ In the event, however, social history was largely confined to the elementary grades, where it was thought to be more suitable to students' level of intellectual development, while in the high schools, political history retained its pride of place as the foundation of education for national citizenship.

Social history was also consistent with the League's argument that the progress of "civilization" should form the organizing theme of all history teaching. To quote the 1927 report of the League's Subcommittee of Experts, "the child must learn that civilization has been, and still is, the common work of all peoples." ${ }^{\prime \prime 6}$ A subsequent League committee on textbook revision repeated this message in 1932, urging that "the history of civilisation and the intellectual, social, economic, and judicial evolution of nations should not be sacrificed to political history." 87 This was a restatement of a position that the League had endorsed for some years and in many ways reflected rather than reshaped what Canadian schools were attempting to do. In 1923, for example, an Alberta school inspector praised the province's grade 9 ancient history text for showing "in a simple, interesting, and fairly comprehensive way the progress of civilization among the peoples of the ancient world" and explaining "the contributions which each has made to the progress of mankind." 88 In a similar spirit, Manitoba's 1928 grade 9 European history course spoke of instilling in students an awareness that people of all cultures are motivated by the same passions and thus are "fellow citizens of the world within." ${ }^{99}$ Nova Scotia's history program made a similar point, reminding teachers that "whatever good there is in our present world is not the 
result of the efforts of any one group, but of all the races. It is the achievement, not of men, but of mankind." 90

\section{How Effective was League Teaching in Canada?}

It is next to impossible to determine the impact of the League's educational campaign on Canadian students. What Canadians were taught in school as students clearly did not result in their taking out membership in the League of Nations Society when they became adults, nor did it create a pro-League public opinion that might have influenced the thinking of Canada's policy-makers. The League of Nations Society lost members as the 1930s progressed. The editor of the Winnipeg Free Press, himself an influential League advocate, noted in 1936 that in Canada the League of Nations Society was "an organization which struggled for existence in the face of apparent public indifference," an indictment shared by at least one disillusioned Society member, who told its 1936 annual conference that businessmen saw it as "an organization of harmless cranks," while its relationship with the churches was a "washout," as it was with the labour movement, veterans, and the military. ${ }^{91}$

According to Micheline Johnson, some Quebec educationists ("les théoriciens de l'enseignement de l'histoire") saw the League's wish to use the teaching of history to create an internationalist outlook in the young as "une théorie dangereuse et ménaçante pour les Canadiens français." ${ }^{2}$ This perhaps helps to explain the ambivalence of Quebec's response to a 1932 League request for information about the training of teachers: "The absence of direct action by the Department of Education and the Committees of the Council of Education is not due to any lack of appreciation of the objects of the League, but solely to the fact that the efforts of the educational authorities and the teaching bodies have to be so earnestly concentrated upon the ordinary cultural and practical subjects of the school courses that additional interests involving examination or/and special training cannot well be undertaken." ${ }^{33}$

As in Quebec, in the rest of Canada students left school having been taught something about the League's existence and its activities, but League of Nations teaching was an add-on to the existing history curriculum and did not challenge its preoccupation with nation-building and national citizenship. Indeed, Canada's membership in the League was treated, not so much as a contribution to the elimination of war, but as a symbol of Canada's achievement of autonomous nationhood; it thus constituted the latest chapter in the nation-building story that formed the organizing backbone of Canadian history curricula. In the words of McArthur's widely used textbook, membership in the League demonstrated that "Canada's status as a nation was acknowledged." ${ }^{4}$

It seems likely that most students at best retained only a factual and probably short-lived knowledge of the League, devoid of any element of the "League spirit" that the League's supporters saw as so crucial. At least until the later 1930s, when it became increasingly clear that a new European war was likely, isolationism, or at least indifference, not internationalism, was the Canadian norm. There is no evidence that their history classes made Canadian students more internationally aware 
than they otherwise might have been. As UBC historian Frank Soward observed in 1931, "Canadians are not hostile to the League but they are not yet internationally minded." 95 Canada's League of Nations Society frequently observed that Canadians who took an interest in international affairs were too few and too isolated to have any impact on the shaping of public opinion. According to McGill University historian Thomas McDermot, League supporters in Canada were also "”overwhelmed with the unimportance of being earnest in this country." ${ }^{66}$ Prime Minister Mackenzie King's advisors agreed, telling him in 1935, in a reference to both the election of a Social Credit government in Alberta and to the Abyssinian crisis, that Canadians were "immensely more interested in Alberta than in Abyssinia." 97 Addressing a radio audience in 1936, Ernest Lapointe, influential federal cabinet minister and close associate of Mackenzie King (and also former president of the League of Nations Society), pursued the same theme, noting that many Canadians were not interested in international affairs ("Un grand nombre de nos compatriotes ne semblent pas se préoccuper suffisament de se bien renseigner sur la politique mondiale.") ${ }^{98}$ In such a climate of opinion, it is not difficult to understand how Canada's schools were unable to implant the League of Nations ideal of the "international mind" in their students.

Particularly notable in this regard is the total silence of the annual reports of provincial departments of education regarding both the League of Nations and international education more generally, though they did find space for discussion of health and hygiene, tree planting, rural education, school fairs, music, Junior Red Cross, technical education, Arbor Day, and other such topics. To take only one example, in 1924, New Brunswick's chief superintendent of schools reported on the ravages of forest fires in the province and concluded that "as our material welfare is at stake, it seems fitting and necessary that careful instruction should be given all pupils as to fire prevention." 99 Throughout the whole interwar period, nothing like this was ever said in any province's annual report about the importance of the League and international cooperation. Nor did school inspectors' instructions in any province include any directive that inspectors should take note of what was being done to teach students about the League or to foster a sense of internationalism in the schools they inspected, though from time to time they did make favourable reference to the activities of the Junior Red Cross, albeit more as a nursery of citizenship than of any international outlook.

From the mid-1930s onwards, it became increasingly clear that the League was facing failure. Speaking in 1936, the vice-president of the Canadian League of Nations Society concluded that the League "had failed to perform its primary function... it has failed to maintain peace and restrain aggression." ${ }^{100}$ This shift in mood goes some way to explaining why the League in 1937 renamed its Sub-committee of Experts on League of Nations Teaching as the Advisory Committee on the Teaching of the Principles and Facts of International Cooperation. In the same spirit, the International Federation of League of Nations Societies resolved at its 1934 congress that "it is no longer sufficient merely to introduce into all schools an explanation of the aims of the League, the machinery it has created and the results it has obtained. All means of maintaining and developing an international culture in the minds both 
of children and of adults must be reinforced." 101 It is as if too close an association with what many observers increasingly saw as a failing organization was considered to be more of a handicap than an advantage. As the ICIC noted in 1938, "the aim is no longer to teach about the League of Nations itself, but to imbue teaching with the separate methods and traditions of that international cooperation of which the League is to-day the most important form." 102

In such a climate, the League-inspired campaign to reform history teaching lost most of whatever impetus it had once enjoyed in Canada and was, in any case, overtaken by the pressures of the Second World War. Given the realities of the international political system, the League's attempts to reshape the teaching of history could never go beyond requests, recommendations, and suggestions to national governments. In the assessment of one contemporary observer, the League's campaign consisted only of "improvisations and additions which, when combined together, did not constitute a global plan to serve as a guide or suggestion for the reorientation of national systems of education in the interests of universal peace." 103 As its critics pointed out, despite its name, the League was not a league of nations or of peoples, but of governments and, in Canada as elsewhere, governments saw the teaching of history in national, and often nationalist, terms. Despite the internationalist rhetoric, history's function in schools was to create national citizens and thereby strengthen the nation-state. As the Manitoba Teacher editorialized in 1929: "After the traditional high school fare of British and Canadian history, it came as a surprise to many students to learn at university that other nations besides Britain had a history of which they might be justly proud... and that other nations had at one time or another surpassed our own." 104

\section{Notes}

1 For more on the League of Nations' attempts to reform history teaching, see Ken Osborne, "Creating the 'International Mind': The League of Nations' Attempts to Reform History Teaching, 1920-1939," History of Education Quarterly 56, no. 2 (May 2016): 213-240; Eckhardt Fuchs, "The Creation of New International Networks in Education: The League of Nations and Educational Organizations in the 1920s," Paedagogica Historica 43, no. 2 (2007): 199-209; Elly Hermon, "Education et vérité: Aspects de la réforme de l'enseignement de l'histoire pendant l'entre-deux-guerres," Réflexions historiques 10, no. 2 (juillet 1983): 295-312.

2 Newton Rowell, The British Empire and World Peace (Toronto: Victoria College Press, 1922), 260.

3 "International Affairs for Young Canadians," Interdependence 9 (April 1932): 56.

4 J. A. Dale, Education and Life: Addresses Delivered at the National Conference on Education and Citizenship, Held at Toronto, April 1923 (Toronto: Oxford University Press, 1924), 283.

5 E. H. Marshall, "Some Thoughts on Our History Aims," Manitoba Teacher (April 1925): 8.

6 Chester Martin, "Canada, the League, and the League Mind," Manitoba Teacher (October 1926): 3-4. 
7 Fred Clarke, Foundations of History Teaching: A Critique for Teachers (London: Oxford University Press, 1929), 167.

8 Nova Scotia Department of Education, Handbook to the Course of Study (Truro: News Publishing Company, 1935), 184.

9 Manitoba Department of Education, Report of the Committee on the Review of the Programme of Studies (Grades VII to XI) (Winnipeg: King's Printer, 1927), 42.

10 Charles Hamblin, The War Myth in American History (New York: Vanguard Press, 1927), 8-9; see also Jonathan F. Scott, The Menace of Nationalism in Education (London: Allen \& Unwin, 1926).

11 Enquête sur les livres scolaires d'après-guerre. Vol. 2 (Paris: Dotation Carnegie pour la Paix Internationale, 1923, 1926), 9.

12 H. G. Wells, "The Traveller Provokes his Old Friends, the Teachers, Again in a Paper Called 'The Poison Called History,'” in his Travels of a Republican Radical in Search of Hot Water (Harmondsworth: Penguin, 1939), 89-121; and see, of course, his bestselling The Outline of History (London: Cassell, 1920). For Wells as an educationist, see Ken Osborne, “'One Great Epic Unfolding': H. G. Wells and the Interwar Debate on the Teaching of History," Historical Studies in Education/Revue d'histoire de l'éducation 26, no. 2 (Autumn 2014): 1-29.

13 For the subcommittee's initial report, see League of Nations Official Journal 8, no. 10 (October 1927): 1209-20.

14 Willis G. T. Airey, "Education for the Great Society, with Some Reflections on the Teaching of History," League of Nations Educational Survey 2, no. 1 (1931): 46-54. The page numbers in parentheses in this and the next paragraph all refer to this article. See also Airey's Onward: A Study of the League of Nations and the Principles of International Cooperation (Christchurch, NZ: L. M. Isitt, 1929).

15 Robert D. Gidney and William P. J. Millar, How Schools Worked: Public Education in Canada, 1900-1940 (Montreal and Kingston: McGill-Queen's University Press, 2012), 31.

16 League of Nations Official Journal 7, no. 5 (May 1926): 716-17. Other provincial responses can be found in League of Nations Official Journal 7, no. 8 (August 1926): 1101, and 9, no. 3 (March 1928): 339-40.

17 See, for example, Alfred Zimmern, Education in International Relations: A Critical Survey," League of Nations Educational Survey 111, no. 1 (March 1932): 9-29, and George H. Green, "Learning to Teach International Understanding," League of Nations Educational Survey 4, no. 1 (March 1933): 84-107.

18 "Education Week February 21-27, 1937," Western School Journal 32 (January 1937): 19.

19 "Education Week February 21-27, 1937," 18.

20 E. Perrier, "Moral Disarmament," League of Nations Educational Survey 3, no. 2 (September 1932): 15.

21 For the stance of successive federal governments towards the League of Nations, see Richard Veatch, Canada and the League of Nations (Toronto: University of Toronto Press, 1975) and John Herd Thompson and Allen Seager, Canada 1922-1939: Decades of Discord (Toronto: McClelland \& Stewart, 1986), 54-56.

22 Ontario Ministry of Education, Programme of Studies for Grades I to VI in the Public and Separate Schools 1937 (Toronto: Ontario Ministry of Education 1937), 59.

23 M. Junkin, "International Understanding," Western School Journal 31, no. 1 (January 1936): 6-7.

24 William A. MacIntyre, "The League of Nations," Western School Journal 29, no. 12 (December 1934): 315.

25 "Many Universities Study League," Bulletin of the League of Nations Society in Canada 3, no. 8 (January 1926): 1. 
26 Isaac L. Kandel, Intellectual Cooperation: National and International (New York: Teachers College Bureau of Publications, 1944), 47.

27 Manitoba Department of Education, Review of the Programme of Studies (Grades VII-XI), 49.

28 Ontario Ministry of Education, Programme of Studies for Grade I to VI, 59.

29 C. G. Markham, "British History in Vocational Schools," The School 24, no. 1 (September 1935): 44.

30 T. W. H. Williams, "The Teaching of Current History," The School 25, no. 1 (September 1936): 34-35.

31 "The National Secretary's Report on the Programme of the Society" in League of Nations Society in Canada, Report of the Annual Meeting, 1934, 91-101.

32 For an example in Canso, NS, see C. R. Dunphy, "The Current Events Club," The School 24, no. 4 (December 1935): 335-37.

33 C. C. Goldring, "After-school Activities in Toronto Schools," The School 24, no. 5 (January 1936): 373-81.

34 Manitoba Department of Education, Annual Report for 1936-37 (Winnipeg: Manitoba Department of Education, 1937), 85.

35 “Junior Red Cross," Western School Journal 19, no. 9 (December 1924): 179. On the Junior Red Cross more generally, see Nancy M. Sheehan, "Junior Red Cross in the Schools: An International Movement, a Voluntary Agency and Curriculum Change," Curriculum Inquiry 17, no. 3 (Autumn 1987): 247-66; and also "The Junior Red Cross Movement in Saskatchewan 1919-29: Moral Improvement through the Schools," in Beyond the Homestead: Rural History on the Prairies, ed. David C. Jones and Ian Macpherson (Calgary: University of Calgary Press, 1985), 67-88.

36 “Junior Red Cross," Western School Journal 20, no. 1 (January 1925): 215.

37 “Peace Day," Western School Journal 32, no. 5 (May 1937): 151.

38 "Draft Syllabus for a Lesson on the League of Nations," Western School Journal 21, no. 3 (March 1926): 693-94.

39 BC Teacher (February-June 1926); Western School Journal (February-December 1927).

40 "The International Labor Organization in Education" Manitoba Teacher (January 1927): 13-14; BC Teacher 8, 2 (October 1928): 39-40.

41 Manitoba Teacher (December 1928): 13.

42 Alfred L. Burt, A Short History of the League of Nations: Its Origin, Organization and Problems (Edmonton: University of Alberta Department of Extension, 1924); League of Nations Society in Canada, A New World, or the League of Nations (Ottawa: League of Nations Society in Canada, 1927).

43 These questions are taken from League of Nations Official Journal 9, no. 3 (March 1928): 340; 56th Annual Report of the Public Schools for the Province of British Columbia, 1926-27 (Victoria: King's Printer, 1927), M164; 58th Annual Report of the Public Schools for the Province of British Columbia, 1928-29 (Victoria: King's Printer, 1929), R177; Examination Board of Manitoba, Examination Papers 1931 (Winnipeg: Examination Board, 1931), np; and "Grade XII History," Western School Journal 31, no. 5 (May 1936): 145-46.

44 On the enterprise method, see Donalda J. Dickie, The Enterprise in Theory and Practice (Toronto: Gage, 1941), and Amy von Heyking, "Implementing Progressive Education in Alberta's Rural Schools," Historical Studies in Education/Revue d'histoire de l'éducation 24, no. 1 (2012): 93-111.

45 G. J. Marr, inspector for St. John, NB, in Annual Report of the Schools of New Brunswick, 1924-25 (Fredericton: King's Printer, 1926), 41.

46 Toronto Board of Education, Annual Report, 1932, 103-04, 116-19.

47 Manitoba Department of Education, Review of the Programme of Studies, Grades VII to $X I, 43$. 
30th Annual Report of the Department of Education of the Province of Alberta, 1935 (Edmonton: King's Printer, 1936), 42.

49 George Wrong to Frank Underhill, September 15, 1921, quoted in Donald Wright, The Professionalization of History in English Canada (Toronto: University of Toronto Press, 2005), 77.

50 Canadian Historical Association, Annual Report, 1925, 11.

51 Annual Report of the Superintendent of Schools for Nova Scotia for the Year Ended July 31st, 1934 (Halifax: King's Printer, 1935), 81.

52 League of Nations Society in Canada, Report of Annual Meeting, 1934, 102.

53 Alberta Department of Education, Handbook for Secondary Schools (Edmonton: Alberta Department of Education, 1927), 98.

54 Manitoba Department of Education, Annual Report for 1926-7 (Winnipeg: King's Printer, 1927), 104.

55 Nova Scotia Department of Education, Handbook, 202.

56 Nova Scotia Department of Education, 234-35.

57 Mary McGeachy, "How Teachers in Canada May Further the Purposes of the League of Nations," Manitoba Teacher (January 1931): 5-7. For more on McGeachy, see M. Kinnear, Woman of the World: Mary McGeachy and International Cooperation (Toronto: University of Toronto Press, 2004).

58 See, for example, "Good Will Day Exercises," Western School Journal 22, no. 5 (May 1927): 166-173; and W. Nelles, "Promoting 'Fairplay,' Friendship and Fidelity among Nations: World Goodwill Day and the Peace Movement in British Columbia Schools during the Interwar Years," BC Historical News 35, no. 1 (Winter 2001-2): 14-18.

59 “Children's Page," Western School Journal 20, no. 9 (November 1925): 540-41.

60 Manitoba Department of Education, Empire Day 1921: Four Empire Builders (Winnipeg: Manitoba Department of Education, 1921), 35.

61 For an example of the League of Nations Society in action, see Thomas P. Socknat, Witness Against War: Pacifism in Canada, 1900-1945 (Toronto: University of Toronto Press, 1987), 109-10. More generally, see Donald Page, "The Institute's Popular Arm: The League of Nations Society in Canada," International Affairs 33 (1977-8): 28-65; and Donald J. Herperger, The League of Nations Society in Canada during the 1930s (MA thesis, University of Regina, 1978).

62 "South-east District," Western School Journal 20, no. 10 (December 1925): 580.

63 Women's International League for Peace and Freedom (WILPF), Report of the Canadian School History Textbook Survey (Toronto: WILPF, 1933), 59. For more on this report, see Ken Osborne, "An Early Example of the Analysis of History Textbooks in Canada," Canadian Social Studies 29, no. 1 (1994): 21-25.

64 WILPF, Canadian School History Textbook Survey, 3.

65 Ian McKay and Jamie Swift, The Vimy Trap or, How We Learned to Stop Worrying and Love the Great War (Toronto: Between the Lines, 2016).

66 George J. Reeve, Canada: Its History and Progress, 1000-1925 (Toronto: Oxford University Press, 1926): 333.

67 Duncan McArthur, A High School History of Canada (Toronto: Gage, 1927), 463.

68 William S. Wallace, A First Book of Canadian History (Toronto: Macmillan, 1928), 210; and his History of the Canadian People (Toronto: Macmillan, 1930), 322.

69 George M. Wrong, A Public School History of Canada (Toronto: Ryerson, 1921), $348-50$.

70 Reeve, Canada: Its History and Progress, 351.

71 MacArthur, A High School History of Canada, 474.

72 Wallace, A First Book of Canadian History, 213.

73 Reeve, Canada: Its History and Progress, 375.

74 MacArthur, A High School History of Canada, 474. 
7576 MacArthur, 474.

76 Charles W. Humphreys, "The Banning of a Book in British Columbia," BC Studies 1, no. 1 (Winter 1988-89): 1-12.

77 Frances Helyar, "Bureaucratic Rationalism, Political Partisanship and Acadian Nationalism: The 1920 New Brunswick Textbook Controversy," History of Education 43, no. 1 (January 2014): 72-86.

78 Reeve, Canada: Its History and Progress, iv.

79 Duncan McArthur, History of Canada for High Schools, rev. ed. (Toronto: Gage, 1938), 499.

80 Wallace, A First Book of Canadian History, 216.

81 Wallace, A First Book of Canadian History, 216, and A History of the Canadian People, 331.

82 P.-E. Farley and Guy Lamarche, Histoire du Canada: Cours supérieur (Montréal: Librairie des Clercs de St-Viateur, 1945), 429-30. The text was first published in 1935.

83 Duncan McArthur, "The Teaching of Canadian History," Ontario Historical Society: Papers and Records 21 (1924): 208.

84 Fred Clarke, The Foundations of History Teaching (London: Oxford University Press, 1929), 60.

85 Manitoba Department of Education, Review of the Programme of Studies Grades VII to $X I, 42$.

86 "Recommendations of the Subcommittee of Experts for the Instruction of Children and Youth in the Existence and Aims of the League of Nations," League of Nations Official Journal 8, no. 10 (October 1927): 1218.

87 "Committee of Experts for the Revision of School Textbooks: Resolutions," League of Nations Educational Survey 3, no. 1 (March 1932): 117.

88 "Report of the Inspector of High Schools," Annual Report of the Department of Education of the Province of Alberta, 1923 (Edmonton: King's Printer 1924), 23.

89 Manitoba Department of Education, Programme of Studies for the Public Schools of Manitoba, 1928 (Winnipeg: Manitoba Department of Education), 35.

90 Nova Scotia Department of Education, Handbook, 201-2.

91 John W. Dafoe, "Canada, the Empire, and the League," Foreign Affairs 14 (1936): 303; J. M. Macdonnell, "Third National Study Project — Concluding Discussion," Interdependence 13, no. 3-4 (1936): 184-185.

92 Micheline Johnson, L'histoire apprivoisée (Montréal: Boréal Express, 1979), 36.

93 "Training of Members of the Teaching Profession Who Are Required to Give Lessons on the League of Nations," League of Nations Educational Survey 4, no. 1 (March 1933): 22.

94 McArthur, History of Canada for High Schools, 473.

95 Frank H. Soward, Canada and the League of Nations (Ottawa: League of Nations Society in Canada, 1931), 36; see also Peter B. Waite, "French-Canadian Isolationism and English Canada: An Elliptical Foreign Policy, 1935-39," Journal of Canadian Studies 18, no. 2 (Summer 1983): 132-48.

96 Thomas W. L. McDermot, "Public Opinion and the Way to Create It," Interdependence 8 (December 1931): 150.

97 The quotation is taken from Donald Page, “The Institute's 'Popular Arm': The League of Nations Society in Canada," International Journal 33, no. 1 (Winter 1977-78): 59.

98 Ernest Lapointe, "L'organisation de la communauté mondiale," Interdependence 13 (1936): 98. For an examination of Canadian attitudes to the League in the 1920s, see Donald Page, Canadians and the League of Nations before the Manchurian Crisis (PhD diss., University of Toronto, 1979).

99 W. S. Carter, "Chief Superintendent's Report," Annual Report of the Schools of New Brunswick, 1923-24 (Fredericton: King's Printer, 1925): liv. 
100 E. J. Tarr, "Third National Study Project: Concluding Discussion," Interdependence 13, no. 3-4 (1936): 190.

101 International Federation of League of Nations Societies Bulletin 35 (January-March 1935): $25-26$.

102 "Work of the International Committee on Intellectual Cooperation at its Twentieth Session," League of Nations Official Journal 19 (November 1938): 921.

103 Isaac L. Kandel, Intellectual Cooperation: National and International (New York: Teachers College Bureau of Publications, 1944), 1.

104 "Some Comments on the Proposed Courses in History," Manitoba Teacher (April 1929): 18. 